\title{
Monitoring the water quality Formoso river of the Amazon Region - Brazil using principal component analysis
}

The expansion of the agricultural frontier poses a major threat to the quality of water bodies and conservation and biodiversity of biomes. In the Tocantins Araguaia, hydrographic region is located the largest irrigated flood type rice project in the world, and in the inter-harvest period, the area is still used for soybean production. Considering the great economic, environmental and social importance of the area, the objective of this study was to evaluate the water quality Considering the great economic, environmental and social importance of the area, the objective of this study was to evaluate the water quality of a river in the Amazon Region, Brazil, and to identify the critical pollution sites in the area of influence of the agricultural project. The monitoring occurred between April 2018 and February 2019, during periods of drought and drought. The water quality was evaluated based on the determination of 34 physical-chemical and 2 microbiological parameters. The comparison of the values obtained with the limits allowed by the legislation for class II waters pointed out samples with high total phosphorus values, which can lead to eutrophication phenomena, concentrations above the expected of metals such as $\mathrm{Fe}$, $\mathrm{Cu}$, and $\mathrm{Mn}$ and samples with low percentage of dissolved oxygen. The main component analysis (PCA) showed little variation along the river, i.e., homogeneity in the different points evaluated in the same collection; however, the comparison between collections with different seasonalities revealed quite divergent results, reinforcing that seasonal variations can aggravate the changes in the water quality of the river.

Keywords: Water contamination; PCA; Water quality indicators; Agricultural boundaries; Environmental changes.

\section{Monitoramento da qualidade da água do rio Formoso na Amazônia - Brasil por meio de análise de componentes principais}

A expansão da fronteira agrícola representa uma grande ameaça à qualidade dos corpos d'água e à conservação e biodiversidade dos biomas. No TocantinsAraguaia, a região hidrográfica concentra o maior projeto de arroz irrigado de inundação do mundo e, na entressafra, a área ainda é utilizada para a produção de soja. Considerando a grande importância econômica, ambiental e social da área, o objetivo deste estudo foi avaliar a qualidade da água. Considerando a grande importância econômica, ambiental e social da área, o objetivo deste estudo foi avaliar a qualidade da água de um rio na região amazônica, Brasil, e identificar os locais críticos de poluição na área de influência do projeto agrícola. O monitoramento ocorreu entre abril de 2018 e fevereiro de 2019 , durante os períodos de estiagem e estiagem. A qualidade da água foi avaliada com base na determinação de 34 parâmetros físico-químicos e 2 microbiológicos. A comparação dos valores obtidos com os limites permitidos pela legislação para águas classe II apontou amostras com elevados valores de fósforo total, que podem levar a fenômenos de eutrofização, concentrações acima do esperado de metais como $\mathrm{Fe}$, $\mathrm{Cu}$ e $\mathrm{Mn}$ e amostras com baixo percentual de oxigênio dissolvido. A análise de componentes principais (PCA) apresentou pouca variação ao longo do rio, ou seja, homogeneidade nos diferentes pontos avaliados em uma mesma coleta; no entanto, a comparação entre coletas com diferentes sazonalidades revelou resultados bastante divergentes, reforçando que as variações sazonais podem agravar as mudanças na qualidade da água do rio.

Palavras-chave: Contaminação da água; PCA; Indicadores de qualidade da água; Limites agrícolas, Mudanças ambientais.

Reviewed anonymously in the process of blind peer

Patricia Martins Guarda (iD)

Universidade Federal do Tocantins, Brasil http://lattes.cnpq.br/2590685798782301 http://orcid.org/0000-0003-0937-6779 patriciaguarda@uft.edu.br

Magale Karine Diel Rambo (iD Universidade Federal do Tocantins, Brasil http://lattes.cnpq.br/8793967773394967 http://orcid.org/0000-0003-2529-9574 magalerambo@uft.edu.br

\section{Mayana Mendes Dias Machado (id} Universidade Federal do Tocantins, Brasil http://lattes.cnpq.br/9075009489142475 http://orcid.org/0000-0001-5872-6320 mayanamdm@hotmail.com
Fabrício de Oliveira Ramos (iD) Universidade Federal do Tocantins, Brasil http://lattes.cnpq.br/0918042902371727 http://orcid.org/0000-0002-4132-375X fabricio-or@hotmail.com

Danylo Bezerra Mendes (iD

Universidade Federal do Tocantins, Brasil http://lattes.cnpq.br/1423908067012346 http://orcid.org/0000-0002-2115-9796 danylobiologo@yahoo.com.br

\section{Emerson Adriano Guarda ic}

Universidade Federal do Tocantins, Brasil http://lattes.cnpq.br/9325128702126305 http://orcid.org/0000-0003-0227-3881 emersonprof@uft.edu.br

\section{José Expedito Cavalcante da Silva (ID) Universidade Federal do Tocantins, Brasil http://lattes.cnpq.br/3164221401108609 http://orcid.org/0000-0002-8776-389X} jecs@mail.uft.edu.br
Referencing this:

GUARDA, P. M.; RAMBO, M. K. D.; MACHADO, M. M. D.; RAMOS, F. O.; MENDES, D. B.; GUARDA, E. A.; SILVA, J. E. C.. Monitoring the water quality Formoso river of the Amazon Region - Brazil using principal component analysis. Revista Ibero Americana de Ciências Ambientais, v.12, n.5, p.94-104, 2021. DOI: http://doi.org/10.6008/CBPC2179-6858.2021.005.0009 


\section{INTRODUCTION}

Safe and available water is vital and indispensable for living beings (DUSAVE et al., 2019), and monitoring water quality is fundamental for water resources management (PINTO et al., 2019). Brazil has an immense diversity of aquatic environments, for various uses, such as human consumption, irrigation and recreation (ARAIAS et al., 2007). However, anthropogenic activities have been rapidly and intensely affecting this water quality and quantity (SOUZA et al., 2016). Irrigation used in agriculture is the most water-intensive anthropic activity in the world, intended for the irrigation of grain, fruit and vegetable crops (QUEIROZ et al., 2008).

The growth of agriculture in the Cerrado of Tocantins also increases the amount of foreign substances that are added to the environment that arrive in different ways in the water bodies. This increase is not only in the quantity used, but in the variety of substances, in the most different types of cultures, which brings a danger to all the biological diversity existing in these aquatic environments.

Contamination, caused by the release into the environment of substances such as fertilizers and pesticides with toxic compounds, occurs in both surface and groundwater (BORTOLETTO et al., 2015; NIU et al., 2019). Even if these substances reach rivers and lakes in small quantities, bioaccumulation will make their action highly harmful along the food chains, which at some point, will reach humans (OLIVEIRA, 2007).

The Tocantins-Araguaia Basin has been suffering several impacts related to the use and occupation of land in activities such as agriculture, livestock, and mining. Cattle ranching, for example, has been causing damage to the trampling of cattle that causes mechanical pressure on the soil and on grasses and herbaceous cover, with this speed of water infiltration decreases (water slowly penetrates the soil), so less water is stored in the soil profile and groundwater levels. In addition, vegetation has been replaced by plantations and pastures (SEPLAN, 2016).

The Formoso River Irrigation project, is considered the world's largest flood-type irrigated rice project, in a continuous area, with a sub-flood system. In the dry period there is production of certified soybeans and watermelon, in the rainy period it is occupied with irrigated rice (SILVA, 2015).

In view of the great economic, social and environmental importance, this study aimed to seasonally evaluate the quality of the surface water of the Formoso River over different periods (dry and rainy season) of the year. Thus, water quality criteria are established in order to ensure environmental protection. Knowledge of these parameters established by legislation ensures the integrity of ecosystems, and its perfect functioning requires that certain physical, chemical and biological conditions be respected (QUEIROZ et al., 2008). The results of these parameters allow an efficient management of water resources in a sustainable manner (BORTOLETTO et al., 2015; PINTO et al., 2019).

\section{METHODOLOGY}

\section{Description of the study area}

According to the hydrographic division of ANA - National Water Agency (ANA, 2018), the Formoso River basin has a drainage area of $21,328.57 \mathrm{~km}^{2}$, about $7.7 \%$ of the total area of the State of Tocantins and 
$5.6 \%$ of the Araguaia River basin. The Formoso River basin covers part of the territory of 21 municipalities in the states of Tocantins and Goiás, between the geographical coordinates $10^{\circ} 28^{\prime}$ and $13^{\circ} 16^{\prime} \mathrm{S}$ and $48^{\circ} 50^{\prime}$ and $49^{\circ} 57^{\prime} \mathrm{W}$.

The Formoso River Irrigation Project is located within the tropical floodplain at the western end of the banana basin, characterized by a low altitude flat area, in the municipality of Formoso do Araguaia, southwest region of the state of Tocantins. It is considered the largest flood-type irrigated rice project in the world, in a continuous area, with a sub-flood system, for the production of certified soybeans in the dry period. The agricultural project region is characterized by a region dominated by agriculture and cattle ranching with few areas of forest and Cerrado Park, as shown in Figure 1.

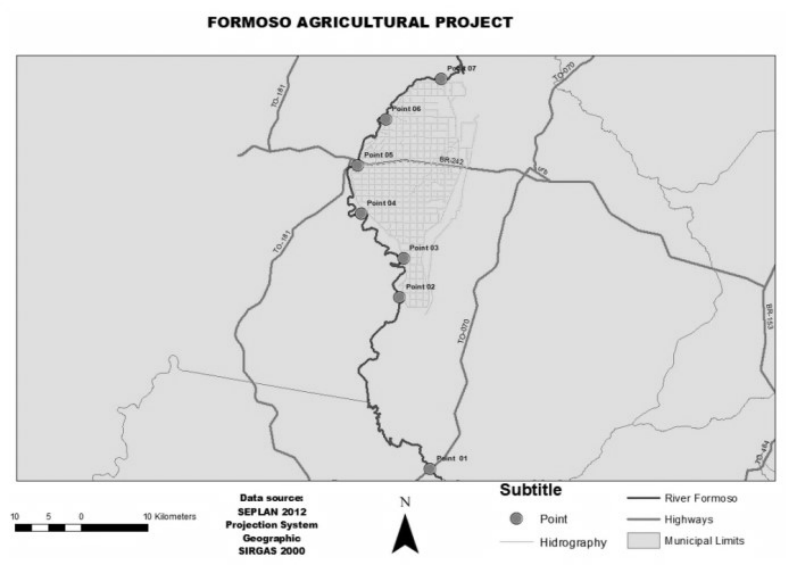

Figure 1: Image with area of the collection points, SEPLAN (2012).

\section{Sampling procedure}

The samples were collected in 7 points of the Formoso River. Selected if a point on the river before it passes through the agricultural project (P1), five points along the project (P2 to P6), one point after the river passes the project margin (P7), as can be seen in Figure 1, with the checkered area being the Agricultural Project. The four campaigns were held on their respective dates: in April 2018 (Campaign - C1), held in the rainy period, July 2018 (Campaign 2 - C2), October 2018 (Campaign 3- C3), held in the dry period and February 2019 (Campaign 4 - C4), held in the rainy period.

The choice of points should cover all of the Formoso River agricultural region. The aim was to verify the project's influence on the contamination of different environmental compartments of the river. One point was sampled on the river before it passed through the agricultural project (P1), $25 \mathrm{~km}$ before the start of the project region; five points were along the project ( $P 2$ to $P 6)$, and one point was after the river passed the project's margin (P7), i.e., $45 \mathrm{~km}$ from P2 to P7, Figure 1 shows.

The points (P4 and (P5), are the points that differ from the others by the absence of riparian forest protecting the river back and separating it from the fields of cultivation. It is observed that in these points the river is more unprotected than the other.

The seasons of the campaigns were chosen randomly, with quarterly frequency to have two samples in rainy period where, in the agricultural project, irrigated rice is planted in almost its entirety and two samples in the dry period, where $70 \%$ of the project is with soybeans for seed and in the other $30 \%$ 
have beans, watermelon and melon.

The choice of monitoring months was based on the beginning of the research project. The concern was to monitor periods when climatic conditions were different and there were different cultures in the agricultural area. The study region has two distinct periods of variations in rainfall and water levels, which are determining factors for the concentration of water-soluble substances.

The rainfall conditions on the days of collection were $11.4 \mathrm{~mm}$ in $\mathrm{C} 1,0 \mathrm{~mm}$ in $\mathrm{C} 2$ and $\mathrm{C} 3$, and 0.6 $\mathrm{mm}$ in C4. The depth of the river reflects these climatic conditions. Only two points (P1 and P5) have depth data, as they have real-time monitoring. In C1, $830 \mathrm{~cm}$ in P1 and $650 \mathrm{~cm}$ in P5; in C2, $275 \mathrm{~cm}$ in P1 and 183 $\mathrm{cm}$ in P5; in C3, $233 \mathrm{~cm}$ in P1 and $158 \mathrm{~cm}$ in P5; and in C4, $413 \mathrm{~cm}$ in P1 and $249 \mathrm{~cm}$ in P5 (SEMARH, 2017, 2018 a, 2018 b, 2018 c, 2018 d).The samples were collected according to (CETESB, 2011), packed in specific containers for each type of analysis, cooled and sent to the Laboratory.

\section{Analysis of physical, chemical and microbiological variables}

Analyses such as $\mathrm{pH}$, air and water temperature, dissolved oxygen (OD), conductivity, turbidity and total dissolved solids, salinity, redox potential were performed using a multiparametric probe (brand: Horiba, model: U-52G) and performed at the collection site, not requiring storage for transport.

The analytical methods used to determine the variables followed the procedures and methodologies recommended in the Standard methods for the examination of water and waste-water (APHA, 2005). For the parameters: chemical oxygen demand, hardness $\left(\mathrm{Ca}^{2+}, \mathrm{Mg}^{2+}\right.$, total), alkalinity (bicarbonate, carbonate, total), chlorides were used the titulometric methods. For the analysis of ammonia, nitrite, nitrate, fluoride, sulfate, sulfide, chlorophyll a, dissolved phosphorus, orthophosphate, total phosphorus, true color, apparent color, the spectrophotometric methods (UV Spectrophotometer/Digital Visible, brand: $\mathrm{HACH}$, model DR5000) were used. The analysis of biochemical oxygen demand, nitrogen used the differentiation method and for organic nitrogen, Kjedal method (Nitrogen Distiller, brand: Tecnal, model: TE-0363) The suspended solids (fixed, total, organic matter) were analyzed by the gravimetric method and Sedimentary Total Solids.

Analysis of metals $\mathrm{Fe}, \mathrm{Al}, \mathrm{Mn}, \mathrm{Cr}, \mathrm{Cu}, \mathrm{Zn}$ by spectrophotometric method (UV Spectrophotometer/Digital Visible, brand: HACH, model DR5000). Total coliforms and Escherichia coli by Colilert method (Incubator model: TE-4200, Tecnal brand scientific equipment and Quanti-Tray Sealer Seder, model 89-10894-02, Sovereign Brazil brand).

Multivariate and statistical analyses were performed using the Unscrambler 10.3 software for principal component analysis (PCA) and Origin. 6.0 for the construction of graphs and illustrative figures. The PCA was performed with the data normalized and using 3 factors, without any type of rotation. The objective of the PCA was to obtain an exploratory analysis verifying possible groupings of samples, and also verifying the relationship that exists between the samples (scores) and the variables (weights) (BERETON, 2000). 


\section{RESULTS AND DISCUSSIONS}

Results obtained with the physical, chemical and microbiological analyses of water.
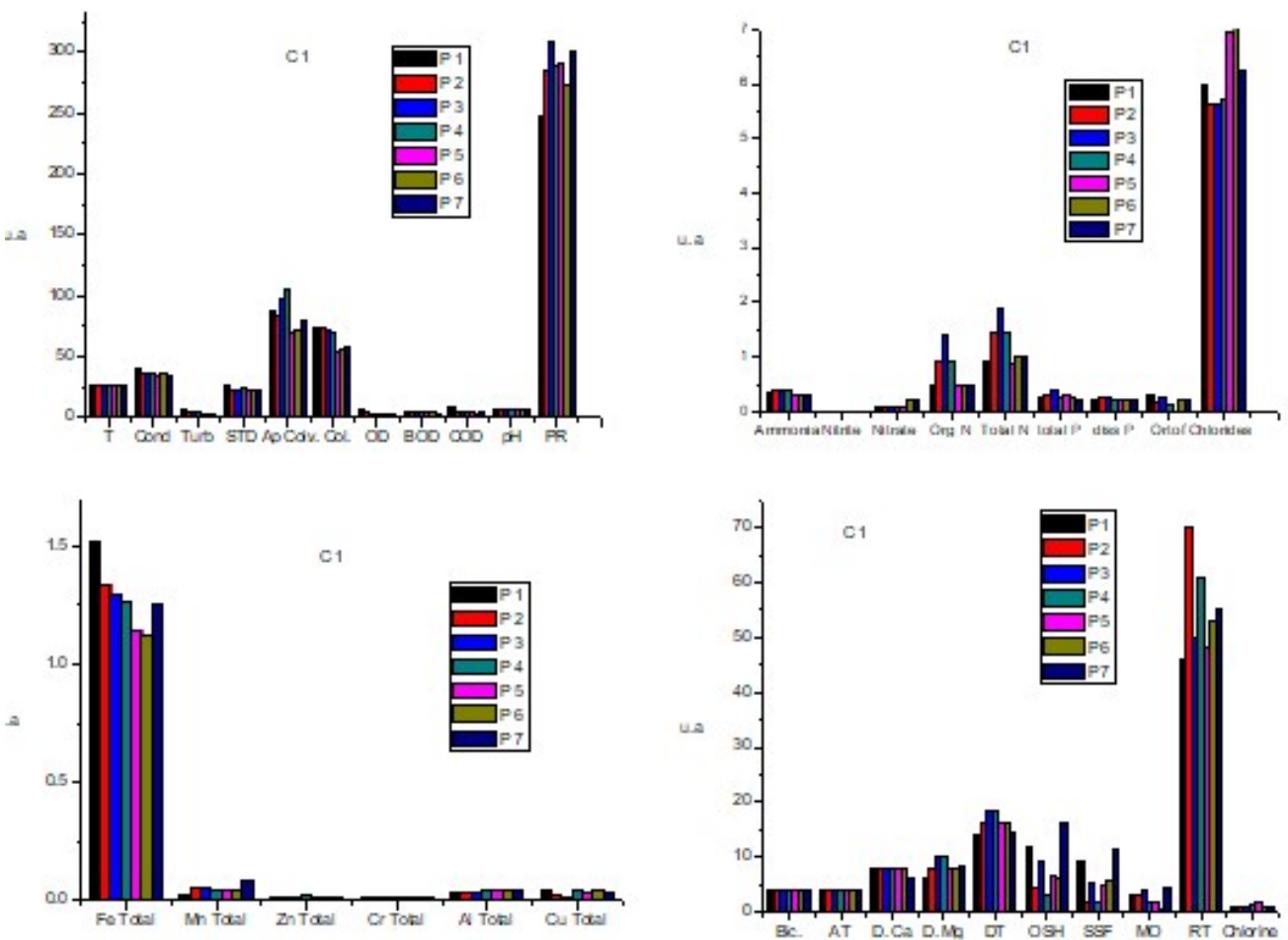

Figure 2: Results of physical and chemical analyzes of water Campaign 1

Parameters Temperature (T), Conductivity (Cond), Turbidity (Turb), Total Dissolved Solids (STD), Apparent Color (Ap Col), True Color (Col), Dissolved Oxygen (OD), Chemical Oxygen Demand (COD), Biochemical Oxygen Demand (BOD), Redox Potential (PR), Organic N (Org N), Dissolved P (Diss P), Orthophosphate (Ortof), Alkalinity-Bicarbonate (Bi), Total Alkalinity (AT), Ca Hardness (D Ca), Mg Hardness (D Mg), Total Hardness (DT), Total Suspended Solids (OSH), Suspended Solids - Fixed Solids (SSF), Suspended Solids - Organic Matter (MO), Total Residues (RT), Chlorophyll a (Chlorine).
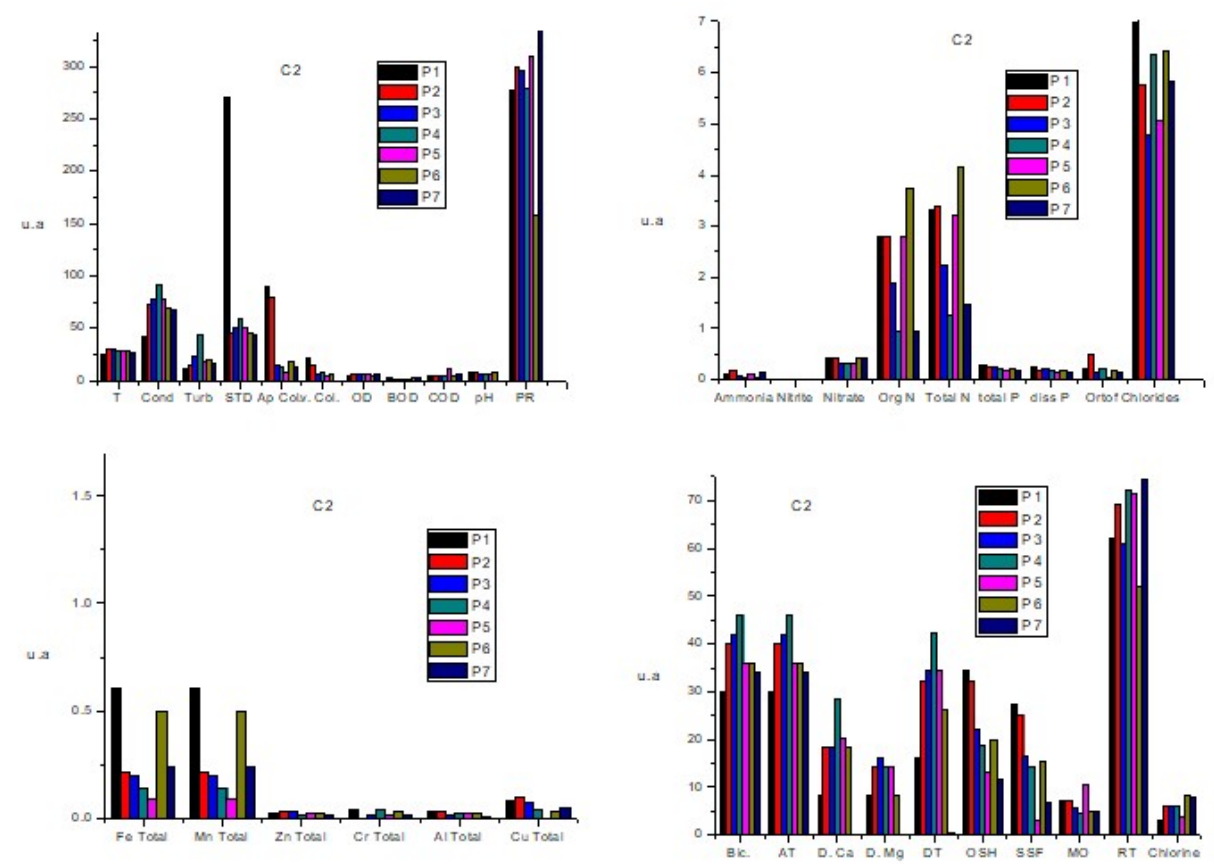

Figure 3: Results of physical and chemical analyzes of water Campaign 2

Parameters Temperature (T), Conductivity (Cond), Turbidity (Turb), Total Dissolved Solids (STD), Apparent Color (Ap Col), True Color (Col), Dissolved Oxygen (OD), Chemical Oxygen Demand (COD), Biochemical Oxygen Demand (BOD), Redox Potential (PR), Organic N (Org N), Dissolved P (Diss P), Orthophosphate (Ortof), Alkalinity-Bicarbonate (Bi), Total Alkalinity (AT), Ca Hardness (D Ca), Mg Hardness (D Mg), Total Hardness (DT), Total Suspended Solids (OSH), Suspended Solids - Fixed Solids (SSF), Suspended Solids - Organic Matter (MO), Total Residues (RT), Chlorophyll a (Chlorine). 

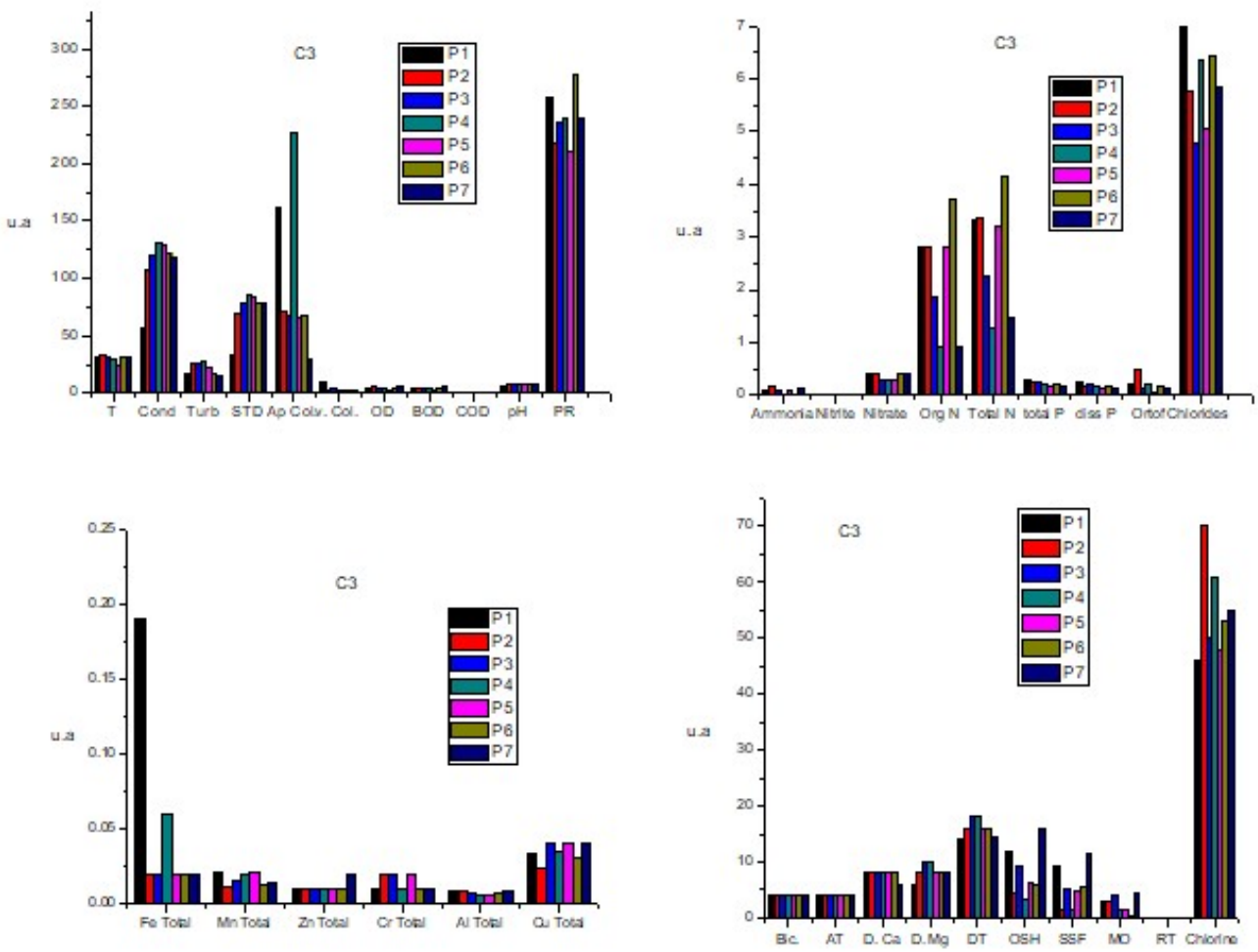

Figure 4: Results of physical and chemical analyzes of water Campaign 3.

Parameters Temperature (T), Conductivity (Cond), Turbidity (Turb), Total Dissolved Solids (STD), Apparent Color (Ap Col), True Color (Col), Dissolved Oxygen (OD), Chemical Oxygen Demand (COD), Biochemical Oxygen Demand (BOD), Redox Potential (PR), Organic N (Org N), Dissolved P (Diss P), Orthophosphate (Ortof), Alkalinity-Bicarbonate (Bi), Total Alkalinity (AT), Ca Hardness (D Ca), Mg Hardness (D Mg), Total Hardness (DT), Total Suspended Solids (OSH), Suspended Solids - Fixed Solids (SSF), Suspended Solids - Organic Matter (MO), Total Residues (RT), Chlorophyll a (Chlorine).
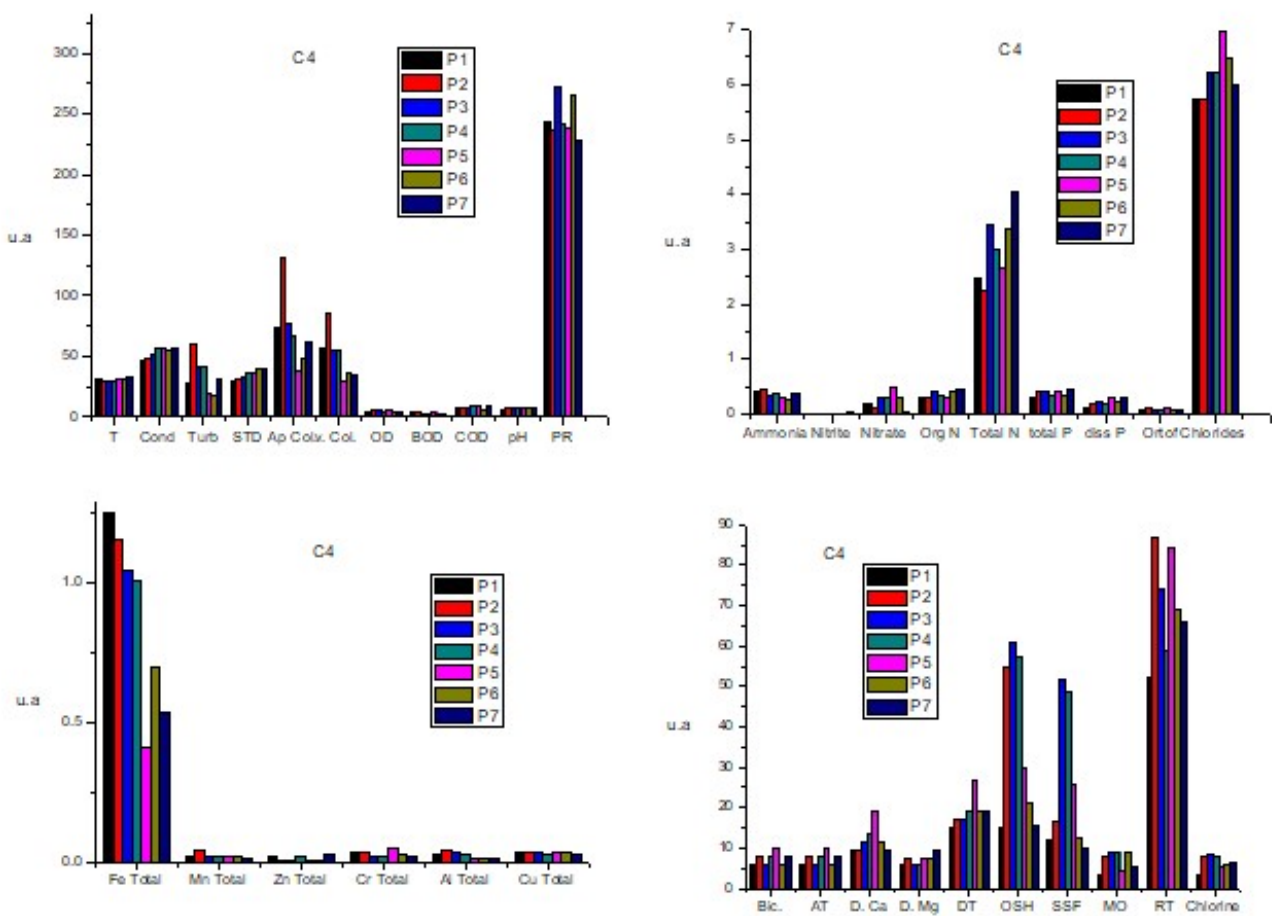

Figure 5: Results of physical and chemical analyzes of water Campaign 4.

Parameters Temperature (T), Conductivity (Cond), Turbidity (Turb), Total Dissolved Solids (STD), Apparent Color (Ap Col), True Color (Col), Dissolved Oxygen (OD), Chemical Oxygen Demand (COD), Biochemical Oxygen Demand (BOD), Redox Potential (PR), Organic N (Org N), Dissolved P (Diss P), Orthophosphate (Ortof), Alkalinity-Bicarbonate (Bi), Total Alkalinity (AT), Ca Hardness (D Ca), Mg Hardness (D Mg), Total Hardness (DT), Total Suspended Solids (OSH), Suspended Solids - Fixed Solids (SSF), Suspended Solids - Organic Matter (MO), Total Residues (RT), Chlorophyll a (Chlorine). 
Principal component analysis (PCA)
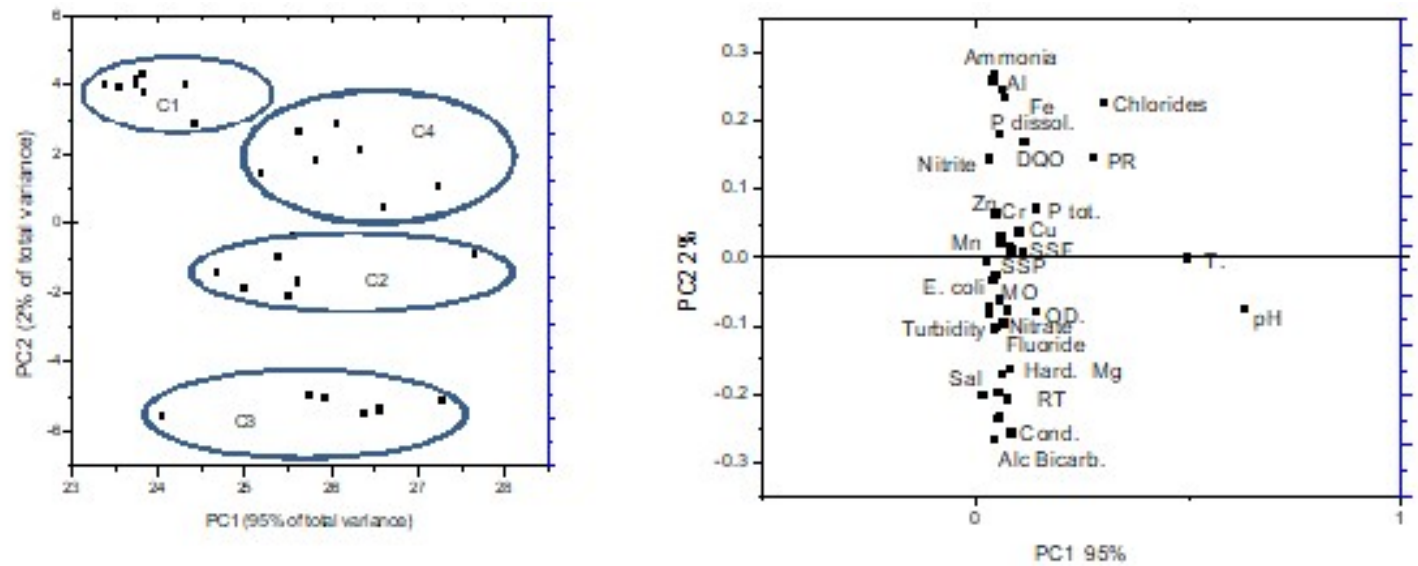

Figure 6: $\mathrm{A}$ and 6B. Analysis of the main components of the sampled points and analyzed parameters. Abbreviation: Temperature ( $T$ ), Conductivity (Cond), Dissolved Oxygen (OD), Chemical Oxygen Demand (DQO), Redox Potential (PR), Dissolved P (P Dissol), Alkalinity-Bicarbonate (Alc Bicarb), Mg Hardness (Hard Mg), Suspended Solids - Fixed Solids (SSF), Suspended Solids - Organic Matter (MO), Salinity (Sal), Escherichia Coli (E Coli).

\section{Evaluation of the results obtained with the physical, chemical and microbiological analyses of water}

The values obtained after the physical, chemical and microbiological analyses are presented in figures 2, 3, 4 and 5. These are compared with the values established by the Brazilian legislation obtained in resolution number 357, of March 17, 2005 of CONAMA (BRASIL, 2005), which establishes water quality classes based on the use of water bodies and determines maximum limits for parameters that ensure the quality and balance of aquatic ecosystems. In the present study, the values for class II were used as reference. It can be observed that some quality parameters are above the values established by legislation, such as the case of total phosphorus.

In aquatic environments, phosphorus can be found in organic and/or inorganic form. In both forms, it may be soluble (dissolved organic matter or salts if phosphorus) or particulate (microbial biomass or mineral compounds). The presence of high concentrations of phosphorus may be linked to natural or anthropic processes (BORTOLETTO et al., 2015). In the Formoso River this high concentration was present throughout the sampled points in the different periods monitored. In rural areas if the phosphorus does not come from natural sources it can be related to the use of fertilizers and pesticides. In the campaigns carried out in the rainy period, the values were higher than in the dry period, indicating that there may have been surface runoff of phosphorus from fertilizers used in the region.

Phosphorus is an important nutrient for the growth of aquatic plants and its high concentration can generate eutrophication and, as a consequence, a drastic reduction in the number of aquatic plant and animal species. Some metals such as iron, copper and manganese have their concentration values above the maximum allowed by the resolution.

The term "heavy metals" has different definitions and most of them take into account the chemical properties of these elements, but the heavy metal concept has been used for a group of metals and semimetals associated with contamination, toxic potential and ecotoxicity (LIMA AND MERÇON, 2014). There are many definitions in relation to this classification. The most correct term in the study of environmental contamination would be toxic metals. The most studied due to its toxicity in humans are $\mathrm{Cd}, \mathrm{Pb}, \mathrm{Cu}, \mathrm{Cr}, \mathrm{Mn}$, 
Hg, Zn (OLIVEIRA, 2007; ALVES et al., 2010; WUANA AND OKIEIMEN, 2011).

In agricultural areas the use of fertilizers emerges as the main source of metal contamination (WUANA et al., 2011; ZHANG et al., 2015). In addition to the fertilizers that have many metals in their composition or as contaminants (WUANA et al., 2011), pesticides also have them.

Although the concentration of these heavy metals in fertilizers is generally controlled and small, either as constituents of the formulation or as impurities, consecutive application to soil causes an accumulation that can be dangerous over time, depending on the amount and form of use (ISLAM et al., 2018).

The contamination of metals by anthropic activities should be subject to constant monitoring and concern due to their toxicity, persistence in the environment, bioaccumulation and bioenlargement in the food chain (DUODU et al. 2017). According to Duodu et al. (2017), the ecological risk associated with heavy metals in the environment is increasing significantly.

Most metals are enriched in the food chain, from aquatic plants and invertebrates to fish and mammals. The higher the trophic level of the organism, the higher the concentration of the metal. This toxicity also depends on the chemical form of the element (speciation), some forms are totally insoluble and thus pass through the organisms and in turn cause no damage. The soluble forms cross the biological protective membranes of the organs and therefore cause damage to the organisms. The availability, toxicity, and mobility, therefore, depend on its chemical speciation (OLIVEIRA, 2007).

Physical factors, such as temperature, thermodynamic, kinetic and biological factors, such as species characteristics, trophic interactions, and physiological/biochemical adaptations influence the bioavailability of metals (TCHOUNWOU et al., 2012).

In biological systems, metals can affect cellular organelles (cell membrane, mitochondria, lysosomes, endoplasmic reticulum, nuclei), as well as enzymes that are involved in metabolism as a whole. Some metal ions interact with DNA and nuclear proteins causing damage to them (TCHOUNWOU et al., 2012). According to (CETESB, 2009), electrical conductivity values higher than $100 \mu \mathrm{S} \mathrm{cm}^{-1}$, indicate impacted environments as was observed in the results found in Campaign 3 of collection at the points on the margin of the Agricultural Project, this was the driest period of monitoring where the results show an enormous environmental impact on the river in this period.

Oxygen dissolved in water is one of the most important indicators of quality in the dynamics of aquatic environments, because this gas is essential for the metabolism of different aerobic organisms present in the river, is fundamental for the balance of these communities (AMORIM et al., 2017). In this monitoring, it remained with low values, indicating an enormous impact to aquatic organisms of the environmental compartments of this river, mainly from the monitoring $\mathrm{P} 4$, what is observed at this collection point is a greater proximity of rural property to the river, not occurring riparian forest protecting the riverbank.

In the state of Tocantins, the Secretariat of Environment and Water Resources (SEMARH, 2017) through the Program to Encourage the Dissemination of Water Quality Data - QUALIÁGUA of the National 
Water Agency (ANA), monitored in 2017 and 2018, the Formoso River, quarterly. In 2017, the results showed that dissolved oxygen was one of the biggest problems found within the parameters analyzed in the state's water resources (SEMARH, 2017), as well as was also observed at the end of the 2018 analyses, verifying several rivers with values lower than those established by legislation (SEMARH, 2018 a, 2018 b, 2018 c, 2018 d).

During this monitoring period, BOD was high $\left(>5 \mathrm{mg} \cdot \mathrm{L}^{-1}\right)$, in points 2 of Campaign 3 and point 7 of Campaign 4. Some parameters did not have significant variations during the analysis, or obtained results below the detection limit and / or quantification of the method. Salinity and Alkalinity-Carbonate (value = 0), Total Coliforms $\left(>2419\right.$ NMP. $\left.100 \mathrm{ml}^{-1}\right)$, Sedimentary Total Solids $\left(<0.1 \mathrm{mg} \cdot \mathrm{L}^{-1} \cdot \mathrm{h}^{-1}\right)$ and ranging Escherichia Coli results varying widely but with values $<2419$ NMP. $100 \mathrm{ml}^{-1}$ at the sampled points, so these results were not added in figures 2, 3, 4 and 5. All other quality indicator parameters are in compliance with the legislation.

\section{Evaluation of variables monitored by principal component analysis (PCA)}

The first two CPs explain 95 and $2 \%$ of the total variance, respectively (Figure 6A). PC1 is characterized by negative weights, typical of samples with high levels of $\mathrm{pH}$, fluoride, nitrate, total hardness, magnesium, turbidity, OD, among other parameters (Figure 6B). Thus, PC1 differentiated samples from those collected in campaigns 1 and 4, and was able to distinguish the dry from the rainy season. Rainy campaigns, on the other hand, showed high levels of chlorides, total and dissolved $\mathrm{P}$, iron, ammonia, BOD and COD, among others (Figure 6B).

The flow and depth of the river varied greatly according to the time of collection. The flow rate in P1 varied from $1 \mathrm{~m}^{3} \cdot \mathrm{s}^{-1}$ in $\mathrm{C} 3$ (dry period) to $55 \mathrm{~m}^{3} \cdot \mathrm{s}^{-1}$ in $\mathrm{C} 4$ (rainy period), as well as the depth from $233 \mathrm{~cm}$ to $414 \mathrm{~cm}$, respectively in these two campaigns. In P5, for example, the river flow varied from $1 \mathrm{~m}^{3} . \mathrm{s}^{-1}$ in C3 (dry period) to $9 \mathrm{~m}^{3} \cdot \mathrm{s}^{-1}$ in C4 (rainy period), as well as the depth from $158 \mathrm{~cm}$ to $249 \mathrm{~cm}$, respectively in these two seasons. The PCA shows that the dynamics of the aquatic environment of this river behaves very differently depending on the dry or rainy period in the region.

Studies carried out with analyzes of different pesticides in the same studied location, have shown that the dry season in the region is the most critical for the quality of the Formoso River and for the environmental biodiversity of that of the different environmental compartments of the river. In these studies, the water contamination of surface water, soil and sediment is greater in the dry period, both in terms of the number of active ingredients and in the concentration of these contaminants (GUARDA et al., 2020).

\section{CONCLUSION}

Was verified that the total phosphorus values were very high, which may cause the eutrophication phenomenon in the studied environment. The results found for dissolved oxygen are too low for what is necessary to maintain the life of aerobic organisms in aquatic environments, and that the concentration of 
metals such as $\mathrm{Fe}, \mathrm{Cu}$ and $\mathrm{Mn}$ are higher than expected, and can be dangerous because they tend to bioaccumulate and/or biomagnify along the food chain.

The analysis of the monitored variables, using PCA, indicated the formation of four distinct groups of parameters distributed according to the collection campaign and for each of them allowed the selection of the most important variables among the parameters evaluated that should be monitored in this river, thus facilitating the choice of monitoring parameters in each sampling season.

This analysis showed that the dynamics of the environment is very different in the dry and rainy period in the region, so it is necessary to monitor more frequently (at least every six months) the water quality of this river in order to assess the real dimension of water contamination, thus being able to carry out the remediation of contaminated areas, plan and manage the use of water in the region, prevent future contamination, thus preserving the biodiversity of aquatic ecosystems in the Cerrado biome.

Due to the extensive use of the river for irrigation, periods have been constant when some areas of the water body have their flow reduced or are completely without water. Control of water use by the agricultural project already exists, where pumping is monitored so that such effects are minimized. Some of the parameters presented show that the water quality of the Rio Formoso decreases during the drought period, showing that water control in the region is necessary. The importance of this work to assist in political and environmental decisions regarding the use of water in the region is evidenced, for agricultural activity.

\section{REFERENCES}

ALVES, R. I. S., TONANI, K. A. A., NIKAIDO, M., CARDOSO, O. O., TREVILATO, T. M. B., SEGURA-MUÑOZ, S. I.. Evaluation of heavy metal concentrations in surface waters and sediment in the Monte Alegre Stream and tributaries, Ribeira Preto, SP, Brazil. Ambi-Água, Taubaté, v.5, n.3, p.122-132, 2010. DOI: https://doi.org/10.4136/ambi-agua.157

APHA. American Public Health Association. Standard methods for the examination of water and waste-water. 21 ed. New York: American Public Health Association, 2005.

AMORIM, D. G., CAVALCANTE, P. R. S., SOARES, L. S., AMORIM, P. L. C. Ordination and evaluation of the water quality index for the creeks Rabo de Porco and Precuá, located in the Premium I Refinery area, municipality of Bacabeira (MA), Brazil. Eng Sanit Ambient, v.22, n.2, p.251259, 2017. DOI: http://dx.doi.org/10.1590/s1413$\underline{41522016131212}$

ANA. Agência Nacional das Águas. Região Hidrográfica do Tocantins-Araguaia. Brasília, 2018.

ARIAS, A. R. L., BUSS, D. F., ALBURQUERQUE, C., INÁCIO, A. F., FREIRE, M. M., EGLER, M.; MUGNAI, R., BAPTISTA, D. F.. Use of bioindicators for assessing and monitoring pesticides contamination in streams and rivers. Ciênc. saúde coletiva, v.12, n.1, p.61-72, 2007. DOI:

http://dx.doi.org/10.1590/S1413-81232007000100011

BERETON, G. R.. Introduction to multivariate celebration in analytical chemistry. The analyst tutorial review. Analyst, v. 125, p.2125-2154, 2000. DOI:

\section{https://doi.org/10.1039/B003805}

BORTOLETTO, E. C., SILVA, H. A., BONIFÁCIO, C. M., TAVARES, C. R. G.. Water quality monitoring of the Pirapó River watershed, Paraná, Brazil. Brazilian Journal of Biology, v.75, n.4, p.148-157, 2015. http://dx.doi.org/10.1590/15196984.00313suppl

BRASIL. Ministério do Meio Ambiente. Resolução CONAMA Resolução N. 357. Dispõe sobre a classificação dos corpos de água e diretrizes ambientais para o seu enquadramento, bem como estabelece as condições e padrões de lançamento de efluentes, e dá outras providências. Brasília: DOU, 2005.

CETESB. Companhia Ambiental do Estado de São Paulo. Guia nacional de coleta e preservação de amostras: água, sedimento, comunidades aquáticas e efluentes líquidos. Brasilia: CETESB, 2011.

CETESB. Companhia Ambiental do Estado de São Paulo. Qualidade das águas interiores no Estado de São Paulo. São Paulo: CETESB, 2009.

DUODU, G. O., GOONETILLEKE, A., AYOKO, G. A.. Potential bioavailability assessment, source apportionment and ecological risk of heavy metals in sedimento $f$ Brisbane River, Australia. Marine Pollution Bulletin, v.117, p.523-531, 2017. DOI: https://doi.org/10.1016/i.marpolbul.2017.02.017

DUSABE, M. C., WRONSKI, T., SILVA, G. S., PLATH, M., ALBRECHT, C., APIO, A.. Biological water quality assessment 
in the degraded Mutara rangelands, northeastern Rwanda. Environ Monit Assess. v.191, n.39, p.1-13, 2019. DOI: https://doi.org/10.1007/s10661-019-7226-5

GUARDA, P. M., PONTES, A. M. S., DOMICIANO, R. S.; GUALBERTO, L. S.; MENDES, D. B.; GUARDA, E. A.; SILVA, J. E. C.. Assessment of Ecological Risk and Environmental Behavior of Pesticides in Environmental Compartments of the Formoso River in Tocantins, Brazil. Arch Environ Contam Toxicol, v.79, p.524-536, 2020. DOI: http://doi.org/10.1007 / s00244-020-00770-7

GUARDA, P. M., PONTES, A. M. S., DOMICIANO, R. S.; GUALBERTO, L. S.; MENDES, D. B.; GUARDA, E. A.; SILVA, J. E. $C$.. Analysis of triazines, triazoles, and benzimidazoles used as pesticides in different environmental compartments of the Formoso River and their influence on biodiversity in Tocantins. Journal of Environmental Science and Health, Part B, v.55, n.9, p.783-793, 2020. DOI:

http://doi.org/10.1080/03601234.2020.1784667

GUARDA, P. M., PONTES, A. M. S., DOMICIANO, R. S.; GUALBERTO, L. S.; MENDES, D. B.; GUARDA, E. A.; SILVA, J. E. C.. Determination of Carbamates and Thiocarbamates in Water, Soil and Sediment of the Formoso River, TO, Brazil . Chemistry \& Biodiversity, v.17, n.4, 2020. DOI: https://doi.org/10.1002/cbdv.201900717

ISLAM, M. S., HOSSAIN, M. B., MARTIN, A., SARKER, M. S. I.. Assessmente of heavy matal pollution, distribution and source apportionment in the sediment from Feni River estuary, Bangladesh. Chemosphere, v.202, p.25-32, 2018. DOI: https://doi.org/10.1016/j.chemosphere.2018.03.077

LIMA, V. F.; MERÇON, F.. Metais pesados no ensino de química. Química Nova na escola, v.33, n.4, p.199-205, 2014 NIU, P., SONG, L. Y. XIONG Y. H., LU, C. J., JUNAID, M., PEI D. S.. Impact of water quality on the microbial diversity in the surface water along the Three Gorge Reservoir (TGR), China. Ecotoxicology and Environmental Safety, v.181, p.412-418, 2019. DOI: https://doi.org/10.1016/j.ecoenv.2019.06.023

OLIVEIRA, M. R.. Investigação da contaminação por metais pesados da água e do sedimento de corrente nas margens do Rio São Francisco e tributários, a jusante da represa da CEMIG, no município de Três Marias, Minas Gerais. Tese (Doutorado em Geologia) - Universidade Federal de Minas Gerais, Belo Horizonte, 2007.

PINTO, C. C.; CALAZANS, G. M.; OLIVEIRA, S. C.. Assessment of spatial variations in the surface water quality of the Velhas River Basin, Brazil, using multivariate statistical analysis and nonparametric statistics. Environ Monit Assess, v.191, n.164, 2019. DOI: https://doi.org/10.1007/s10661019-7281-y
QUEIROZ, J. F.; SILVA, M. S. G. M.; STRIXINO, S. T.. Organismos Bentônico: biomonitoramento de qualidade de água. Embrapa Meio Ambiente, 2008.

SEMARH. Secretaria do Meio Ambiente e Recursos HídricosGoverno do Tocantins. Boletim de qualidade de água, 2017.

SEMARH. Secretaria do Meio Ambiente e Recurso HídricosGoverno do Tocantins. Boletim de qualidade de água, 2018.

SEMARH. Secretaria do Meio Ambiente e Recursos HídricosGoverno do Tocantins. Boletim de qualidade de água: Boletim Trimestral 3, 2018

SEMARH. Secretaria do Meio Ambiente e Recursos HídricosGoverno do Tocantins. Boletim de qualidade de água: Boletim Trimestral 4, 2018

SEPLAN. Secretaria do Planejamento e Orçamento Governo do Estado do Tocantins. Perfil Do Agronegócio Tocantinense-Versão Final, 2016

SEPLAN. Secretaria do Planejamento e Orçamento Governo do Estado do Tocantins. Base de Dados Geográficos do Estado do Tocantins, 2012.

SILVA A. J. R.. Sensoriamento remoto como subsídio para a gestãoagrícola: estudo de caso do Projeto de Irrigação Rio Formoso -Formoso do Araguaia-TO. Dissertation. Federal Institute of Science andTechnology Education of Goiás, Goiânia. 2015

SOUSA, A. C., CRUZ, A. D., OLIVEIRA, G. J. S.; FELIX, A. M. C.; NUNES, R. K. F., ALVES, G. S.. Análise exploratória da qualidade da água tratada, armazenada em caixas-d'água do bairro do Roger, em João Pessoa-PB. Principia, v.29, p.110118, 2016

TCHOUNWOU, P. B., YEDJOU, C. G., PATLOLLA, A. K. SUTTON, D. J.. Heavy Metals Toxicity and the Environment. EXS, v.101, p.133-164, 2012. DOI: doi:10.1007/978-3-76438340-4 6

WUANA, R. A.; OKIEIMEN, F. E.. Heavy metals in contaminated soils: A review of sources, chemistry, risks and best available strategies for remediation. SRN Ecology, 2011. DOI: http://dx.doi.org/10.5402/2011/402647

ZHANG, X., ZHONG, T., LIU, L., OUYANG, X.. Impact of Soil Heavy Metal Pollution on Food Safety in China. PLoS ONE, v.10, n.8, 2015. DOI: https://doi.org/10.1371/journal.pone.0135182

A CBPC - Companhia Brasileira de Produção Científica (CNPJ: 11.221.422/0001-03) detém os direitos materiais desta publicação. Os direitos referem-se à publicação do trabalho em qualquer parte do mundo, incluindo os direitos às renovações, expansões e disseminações da contribuição, bem como outros direitos subsidiários. Todos os trabalhos publicados eletronicamente poderão posteriormente ser publicados em coletâneas impressas sob coordenação da Sustenere Publishing, da Companhia Brasileira de Produção Científica e seus parceiros autorizados. Os (as) autores (as) preservam os direitos autorais, mas não têm permissão para a publicação da contribuição em outro meio, impresso ou digital, em português ou em tradução. 